\title{
First record of Neoxysomatium brevicaudatum through the non-invasive sampling of Anguis fragilis: complementary morphological and molecular detection
}

\author{
R. Jones ${ }^{1 \dagger}$, D.S. Brown ${ }^{1 \dagger}$, E. Harris ${ }^{2}$, J. Jones ${ }^{3}$, W.O.C. Symondson ${ }^{1}$, \\ M.W. Bruford ${ }^{1}$ and J. Cable ${ }^{1 *}$ \\ ${ }^{1}$ School of Biosciences, Cardiff University, Cardiff CF10 3AX, UK: \\ ${ }^{2}$ Natural History Museum, Cromwell Road, London SW7 5BD, UK: \\ ${ }^{3}$ Capita Symonds, Tŷ Gwent, Lake View, Llantarnam Park, Cwmbran \\ NP44 3HR, UK
}

(Received 10 February 2011; Accepted 28 March 2011; First Published Online 6 May 2011)

\begin{abstract}
Relatively few studies have examined the parasite fauna of British reptiles, partly due to the cryptic nature and low population density of these hosts. Here we examined 12 populations of the slow worm Anguis fragilis which, unlike other UK lizards, occurs at locally high population densities. Morphological examination of non-invasively collected faecal samples revealed the presence of Neoxysomatium brevicaudatum and a second unidentified nematode species. Although previously unrecorded from slow worms in the UK, N. brevicaudatum was present in $38 \%$ of animals (mean intensity 70.9, range 1-686). Morphological identification was confirmed by sequencing the $18 \mathrm{~S}$ ribosomal gene. The use of the species-specific, cytochrome oxidase I mitochondrial gene primers proved an efficient alternative to conventional, microscope screening for parasites, although the original identification of $N$. brevicaudatum was dependent upon morphological characters. Sequencing also identified the second, smaller nematode as belonging to the Rhabdiasidae family: this species was even more common at a prevalence of $83 \%$ (mean intensity 102.8, range 1-2000). While increasing our knowledge of the UK macroparasite fauna, this work demonstrates the benefits of a combined morphological-molecular approach.
\end{abstract}

\section{Introduction}

Slow worms (Anguis fragilis) are a protected reptile species in the UK, requiring translocation of animals prior to land development. Parasite communities have never been examined in UK slow worms before, yet they may be an important consideration for translocation programmes and the choosing of appropriate receptor sites. From dissections of slow worms in Eastern Europe, nine species

*Fax: + 44(0)029 20874116

E-mail: cablej@cardiff.ac.uk

${ }^{\dagger}$ Both authors contributed equally to this work. of parasitic nematode have previously been recorded (Shimalov et al., 2000; Borkovcová \& Kopřiva, 2005; Mihalca et al., 2007), with prevalence of Neoxysomatium brevicaudatum (Zeder, 1800) ranging from 11\% (Shimalov et al., 2000) to 43\% (Borkovcová \& Kopřiva, 2005), and the number per host ranging between 3 and 10. Three nematode species belonging to Rhabdiasidae were reported in the same studies: Paraentomelas dujardini (Maupas 1916), Entomelas entomelas (Dujardin 1945) and Rhabdias fuscovenosus (Railliet 1899).

Our primary aim in this study was to use non-invasive faecal analysis to investigate the prevalence and intensity of gastrointestinal parasites in slow worms from the UK. 
Table 1. Neoxysomatium brevicaudatum and unidentified gastrointestinal nematode infections (prevalence, mean intensity and range) from Anguis fragilis $(n=100)$ in Wales, UK. Data presented from morphological screening only.

\begin{tabular}{|c|c|c|c|c|c|}
\hline \multicolumn{2}{|c|}{ Site } & \multicolumn{2}{|c|}{ Neoxysomatium brevicaudatum } & \multicolumn{2}{|c|}{ Unidentified juveniles (rhabditid) } \\
\hline Llandysul & N52:01:31, W4:21:01 & $1 / 4(25 \%)$ & $1(1)$ & $3 / 4(75 \%)$ & $22.3(19-28)$ \\
\hline Llysdinam & N52:12:39, W3:28:10 & $2 / 2(100 \%)$ & $1(1)$ & $1 / 2(50 \%)$ & $5(5)$ \\
\hline Machen & N51:35:56, W3:08:05 & $0 / 2(0 \%)$ & & $2 / 2(100 \%)$ & $23(22-24)$ \\
\hline Pentwyn & N51:43:20, W3:17:15 & $0 / 3(0 \%)$ & & $3 / 3(100 \%)$ & $9(3-20)$ \\
\hline Pontypool & N51:41:57, W3:04:18 & $1 / 12(8.3 \%)$ & $29(29)$ & $9 / 12(75 \%)$ & $12.1(1-41)$ \\
\hline St Athan & N51:24:14, W3:27:04 & 8/11 (72.7\%) & $53.5(1-173)$ & $11 / 11(100 \%)$ & $304.8(4-1285)$ \\
\hline St Bride's Major & N51:27:60, W3:34:12 & $22 / 50(44 \%)$ & $101(1-686)$ & $41 / 50(82 \%)$ & $108.4(2-2000)$ \\
\hline Total & & $38 / 100(38 \%)$ & $70.9(1-686)$ & $83 / 100(83 \%)$ & $102.8(1-2000)$ \\
\hline
\end{tabular}

Furthermore, we tested the accuracy of a polymerase chain reaction (PCR)-based approach for detecting $N$. brevicaudatum in faeces.

\section{Materials and methods}

\section{Morphological identification}

During the course of a long-term study on slow worm translocations, we collected faecal samples from 100 specimens of the slow worm (A. fragilis) between 2006 and 2009 from locations in Wales (see table 1). Animals recovered from artificial refugia were photographed, measured and weighed. During this brief handling period, approximately one-third of lizards naturally defecated and these samples were stored in sterile vials containing $90 \%$ ethanol. Once returned to the laboratory, each sample was examined under a dissecting microscope (up to $\times 30$ magnification). Two nematode species were recovered and counted. They were cleared in beechwood creosote and examined under a high-power Olympus microscope at the Natural History Museum, London. The larger of the two was identified as N. brevicaudatum (Zeder, 1800). Parasite terminology describing distribution in the host populations is according to Bush et al. (1997).

\section{Molecular identification}

Nematode DNA was extracted using the DNeasy Tissue Kit (Qiagen, Crawley, Sussex, UK) following the Animal Tissues protocol. DNA was amplified using PCR with 18S rDNA primers rift and 1500R (Tkach et al., 2006) using the following conditions: $1 \times$ buffer, $2 \mathrm{mM} \mathrm{MgCl}$, $0.1 \mathrm{~mm}$ deoxynucleotide triphosphates (dNTPs; Invitrogen, Paisley, Renfrewshire, UK), $0.5 \mu \mathrm{M}$ of each primer, $0.45 \mathrm{U}$ Taq polymerase (Invitrogen) and $5 \mathrm{ng} / \mu \mathrm{l}$ DNA in a total volume of $25 \mu \mathrm{l}$, with an initial denaturation at $94^{\circ} \mathrm{C}$ for $3 \mathrm{~min}, 45 \mathrm{cycles}$ of $94^{\circ} \mathrm{C}$ for $20 \mathrm{~s}, 47^{\circ} \mathrm{C}$ for $1 \mathrm{~min}$ and $72^{\circ} \mathrm{C}$ for $1 \mathrm{~min}$, and a final extension at $72^{\circ} \mathrm{C}$ for $5 \mathrm{~min}$. Sequencing was performed on an ABI 3100 automated capillary DNA analyser (ABI Prism model 3100, Beaconsfield, Bucks, UK). Comparison of the 588-bp sequence (accession number JF713457) for the larger nematode with those on GenBank returned a closest match of $99 \%$ similarity to Cosmocercoides dukae. Sequences of the large and small nematodes were then compared with those from 27 nematode species downloaded from GenBank (representative of two orders and eight families) using neighbour-joining analysis in Mega 3.1 (Kumar et al., 2004). Bootstrap analysis was performed with 1000 repetitions.

\section{Molecular screening}

DNA was extracted from ten slow worm faecal samples (collected from: Verwood, Dorset, N51:22:40, W3:13:13, $n=8$; and Caerphilly, Vale of Glamorgan, N50:52:04, W1:51:15, $n=2)$ using the QIAamp ${ }^{\circledR}$ DNA Stool Mini Kit (Qiagen) in accordance with the manufacturer's instructions. For the initial step of the protocol, the faecal sample was vortexed and lysed in buffer for $1 \mathrm{~min}$, with the remainder of the extraction process carried out on the supernatant. This brief lysis is sufficient to extract nematode DNA without significantly damaging the specimen, permitting post-extraction morphological identification under a microscope. DNA (host and parasite) extraction success was established by screening with the universal primers LCO1490 (Folmer et al., 1994) and CI-N-1777 (Brown et al., submitted) which amplify a 287-bp fragment of the cytochrome oxidase I (COI) mitochondrial gene. PCR conditions were as described previously for the $18 \mathrm{~S}$ rDNA primers (see above). Amplification success of DNA was confirmed by gel electrophoresis. With all extractions testing positive, N. brevicaudatum-specific primers COI-J1764 and COI-N-1938 (Brown et al., submitted) were used to amplify a 174-bp fragment of the COI mtDNA gene from the faecal samples. PCR conditions, as described above, included an initial denaturation at $94^{\circ} \mathrm{C}$ for $5 \mathrm{~min}, 40$ cycles of $94^{\circ} \mathrm{C}$ for $30 \mathrm{~s}, 66^{\circ} \mathrm{C}$ for $45 \mathrm{~s}$ and $72^{\circ} \mathrm{C}$ for $45 \mathrm{~s}$, and a final extension at $72^{\circ} \mathrm{C}$ for $10 \mathrm{~min}$. All PCRs were performed on a Peltier Thermal Cycler (Bio-Rad Laboratories, Hercules, California, USA).

\section{Results}

Screening of 100 faecal samples from Welsh slow worms revealed two gastrointestinal nematode species, but no other macroparasites. The larger nematodes were identified morphologically as N. brevicaudatum 
(Zeder, 1800) (prevalence 38\%, mean intensity 70.9 , range 1-686; table 1). There were insufficient morphological characters to explicitly identify the smaller, more common nematode (prevalence $83 \%$, mean intensity 102.8, range 1-2000). However molecular identification placed it in the Rhabditae family, with the highest similarity $(96 \%)$ to Rhabditoides regina (fig. 1).

From a further ten slow worm faecal samples screened with $N$. brevicaudatum-specific COI primers, four samples (from both Dorset and Caerphilly) tested positive. Subsequent examination of the same faecal samples by microscopy recorded these four samples as having at least one $N$. brevicaudatum present in each (1-2 adults), in addition to the smaller nematodes (range 66-861). Of the six faecal samples that were negative by molecular screening, none were found to contain any $N$. brevicaudatum, but four did contain the smaller nematodes (range 28-31).

\section{Discussion}

For the first time $N$. brevicaudatum was recorded from UK slow worms. This parasite infects the intestine of amphibians (e.g. Bombina, Bufo, Hyla, Rana, Triturus) and occasionally reptiles (e.g. Anguis, Natrix) (see Shimalov \& Shimalov, 2000; Shimalov et al., 2000; Kirin, 2002; Karadeniz et al., 2005; Saglam \& Arikan, 2006). It has a direct life-cycle, the eggs hatching outside the host and the first-stage larvae developing and moulting twice to the infective third stage. It is probable that the final host becomes infected orally, the larvae often being found in the tissues (Vashetko \& Siddikov, 1999; Saeed et al., 2007). Males range from 3 to $4 \mathrm{~mm}$ in length, with the females slightly larger at $4-5 \mathrm{~mm}$. The nematode is ovoviviparous with eggs measuring $0.09 \times 0.05 \mathrm{~mm}$ (Ryzhikov et al., 1980). It is a common pathogen

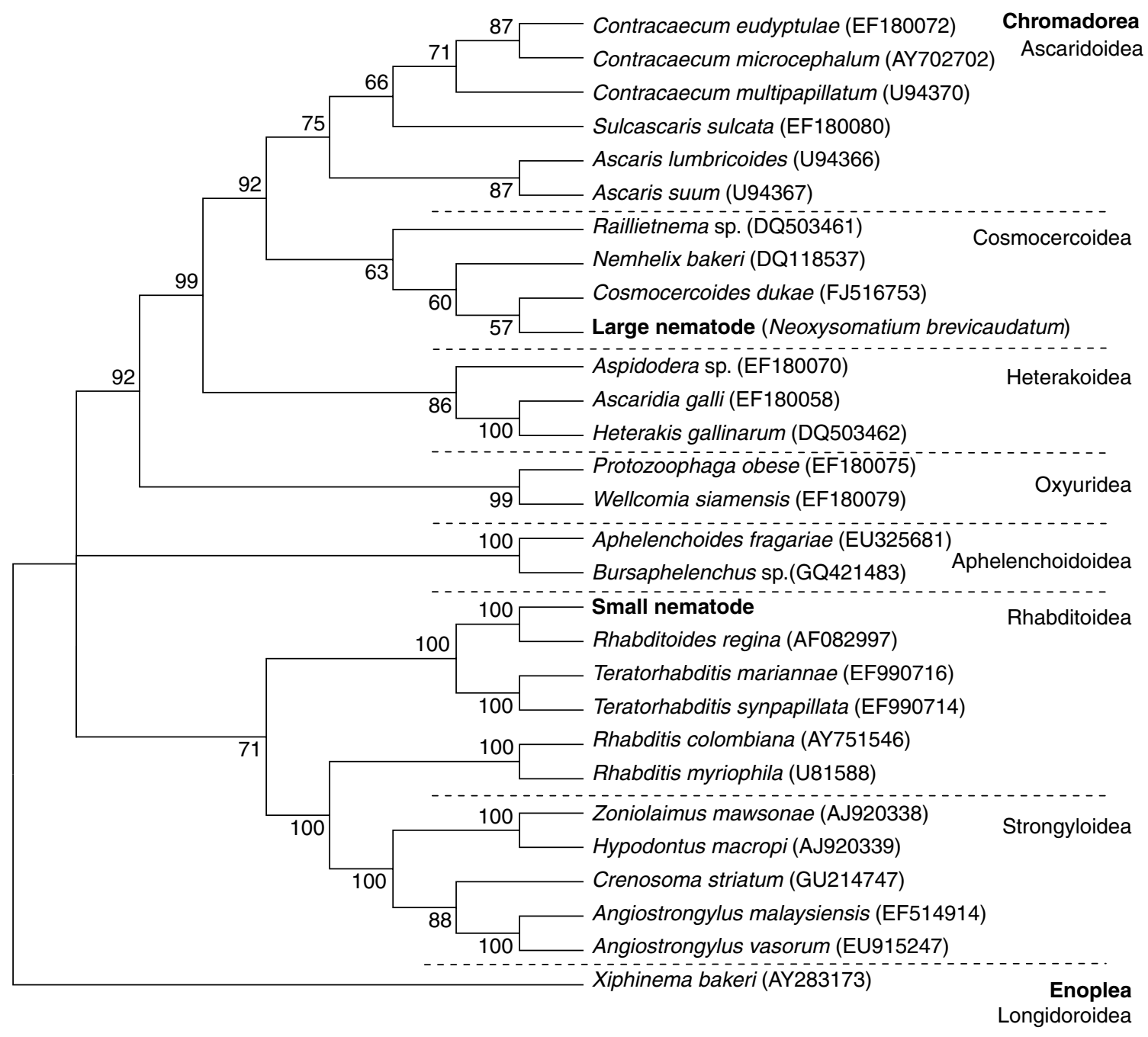

Fig. 1. Neighbour-joining tree showing the relationship of the two nematodes found in UK slow worm faeces (large nematode $=$ Neoxysomatium brevicaudatum and small nematode $=$ unidentified Rhabditidae) with other nematode species. GenBank accession numbers are given in parentheses and all species are grouped into two orders (highlighted in bold) and their respective superfamilies. The tree was constructed based on $588 \mathrm{bp}$ of the $18 \mathrm{~S}$ rDNA sequence and bootstrap analysis was performed with 1000 repetitions. 
of herpetofauna throughout Europe (Yamaguti, 1961; Sharpilo, 1974; Kirin \& Buchvaov, 2002; Borkovcová \& Koprriva, 2005; Saglam \& Arikan, 2006) but has not apparently been recorded previously from slow worms in the UK. This is yet another example of the current lack of knowledge of the helminth parasites of British vertebrates.

Rhabdiasidae nematodes are parasites of vertebrates but not just gastrointestinal, in fact Rhabdias species infect the lungs of amphibians and reptiles (e.g. Kuzmin et al., 2003; Tkach et al., 2006). The Rhabdiasidae belong to the superfamily Rhabditidoidea, which includes Entomelas entomelas found in the oesophagus and rarely the lungs (Baker, 1980). Rhabditid nematodes are common parasites of insects and molluscs. For example, $R$. regina infects beetles (Schulte \& Poinarj, 1991) while Phasmarhabditis hermaphrodita is a common parasite of slugs (e.g. Wilson et al., 1993), which are the major prey of slow worms. Thus, it is possible that the species recovered in the current study originated from slow worm prey or it could be a free-living, bacteria-eating rhabditid which lives in faeces. Both of these explanations are unlikely, however, as records of parasites passing alive through the gut of a predator are rare (Ponton et al., 2010) and most of the faecal samples in the current study were freshly collected from slow worms so there was no (see Jones et al., 2008) or very little opportunity for contamination with free-living nematodes.

Quantitatively, we would expect much higher parasitic loads from dissected animals, but non-invasive faecal sampling has provided valuable data on prevalence and a measure of parasite load. In the faecal samples screened with $N$. brevicaudatum-specific COI primers, prevalence was determined to be $40 \%$, which was corroborated by microscopy. This indicates that molecular screening is as efficient as conventional methods and offers an alternative to the time-consuming and laborious process of hand-sorting, and one which does not require skilled nematode taxonomists. However, an essential prerequisite of molecular screening was the original morphological identification of the samples, as identification through sequencing alone would only have identified $N$. brevicaudatum to family level. Also, the current molecular approach used here could only provide information on prevalence, although other studies have shown real-time PCR as a suitable method for ascertaining intensity (e.g. Nielsen et al., 2008).

Our current studies are assessing the potential fitness consequences of $N$. brevicaudatum and the rhabditid nematode on slow worms. If both parasites are ubiquitous in UK populations, then their presence is not a barrier for translocation exercises. However, if some populations are naïve (which unfortunately can not be assessed from the current study due to small sample sizes), it may be necessary to avoid translocations if animals are infected at either the donor or receptor sites.

\section{Acknowledgements}

This work was supported by a Cardiff University studentship to R.J. and, from the Natural Environment Research Council, a studentship (NER/S/A/2005/13133) to D.S.B. and an Advanced Research Fellowship (NER/J/S/2002/00706) to J.C.

\section{References}

Baker, M.R. (1980) Revision of Entomelas Travassos, 1930 (Nematoda: Rhabdiasidae) with a review of genera in the family. Systematic Parasitology 1, 83-90.

Borkovcová, M. \& Kopřiva, J. (2005) Parasitic helminths of reptiles (Reptilia) in South Moravia (Czech Republic). Parasitology Research 95, 77-78.

Bush, A.O., Lafferty, K.D., Lotz, J.M. \& Shostak, A.W. (1997) Parasitology meets ecology on its own terms: Margolis et al. revisited. Journal of Parasitology 83, 575-583.

Folmer, O., Black, M., Hoeh, W., Lutz, R. \& Vrijenhoek, R. (1994) DNA primers for amplification of mitochondrial cytochrome oxidase subunit I from diverse metazoan invertebrates. Molecular Marine Biology and Biotechnology 3, 294-299.

Jones, R., Cable, J. \& Bruford, M.W. (2008) An evaluation of non-invasive genetic analysis in Northern European reptiles. Herpetological Journal 18, 32-39.

Karadenız, E., Gürkan, E. \& Koyun, M. (2005) Metazoan parasites of the marsh frog (Rana ridibunda Pallas 1771; Anura) collected from the different regions in Turkey. Turkiye Parazitoloji Dergisi 29, 135-139.

Kirin, D. (2002) New records of the helminth fauna from grass snake, Natrix natrix L., 1758 and dice snake, Natrix tessellata Laurenti, 1768 (Colubridae: Reptilia) in South Bulgaria. Acta Zoologica Bulgarica 54, 49-53.

Kirin, D. \& Buchvaov, G. (2002) Biodiversity of the helminth communities of acaudated amphibians (Amphibia - Ecaudata) from Bistritsa riverside (Gotse Delchev region). Experimental Pathology and Parasitology 5, 13-16.

Kumar, S., Tamura, K. \& Masatoshi, N. (2004) MEGA3: integrated software for molecular evolutionary genetics analysis and sequence alignment. Briefings in Bioinformatics 5, 150-163.

Kuzmin, Y., Tkach, V.V. \& Snyder, S.D. (2003) The nematode genus Rhabdias (Nematoda: Rhabdiasidae) from amphibians and reptiles of the Nearctic. Comparative Parasitology 70, 101-114.

Mihalca, A.D., Gherman, C., Ghira, I. \& Cozma, V. (2007) Helminth parasites of reptiles (Reptilia) in Romania. Parasitology Research 101, 491-492.

Nielsen, M.K., Peterson, D.S., Monrad, J., Thamsborg, S.M., Olsen, S.N. \& Kaplan, R.M. (2008) Detection and semi-quantification of Strongylus vulgaris DNA in equine faeces by real-time quantitative PCR. International Journal for Parasitology 38, 443-453.

Ponton, F., Lebarbenchon, C., Lefèvre, T., Biron, D.G., Duneau, D., Hughes, D.P. \& Thomas, F. (2010) Parasite survives predation on its host. Nature 440, 756.

Ryzhikov, K.M., Sharpilo, V.P. \& Shevechenko, N.N. (1980) Helminths of amphibians of the fauna of the USSR. Moscow, Russia, Izdatel'stov Nauka. 
Saeed, I., Al-Barwari, S.E. \& Al-Harmni, K.I. (2007) Metazoan parasitological research of some Iraqi amphibians. Türkiye Parazitoloji Dergisi 31, 337-345.

Saglam, N. \& Arikan, H. (2006) Endohelminth fauna of the marsh frog Rana ridibunda from Lake Hazar, Turkey. Diseases of Aquatic Organisms 72, 253-260.

Schulte, F. \& Poinarj, G.O. (1991) Description of Rhabditis (Rhabditoides) regina n. sp. (Nematoda: Rhabditidae) from the body cavity of beetle larvae in Guatemala. Revue Nématology 14, 151-156.

Sharpilo, V.P. (1974) A new member of the Genus Neoxysomatium Nematoda Cosmocercidae a parasite of slow worms of the Caucasus. Parazitologiya 8, $112-115$.

Shimalov, V.V. \& Shimalov, V.T. (2000) Helminth fauna of snakes (Reptilia, Serpentes) in Belorussian Polesye. Parasitology Research 86, 340-341.
Shimalov, V.V., Shimalov, V.T. \& Shimalov, A.V. (2000) Helminth fauna of lizards (Reptilia, Sauria) in the southern part of Belarus. Parasitology Research 86, 343.

Tkach, V.V., Kuzmin, Y. \& Pulis, E.E. (2006) A new species of Rhabdias from lungs of the wood frog, Rana sylvatica, in North America: the last sibling of Rhabdias ranae? Journal of Parasitology 92, 631-636.

Vashetko, E.V. \& Siddikov, B.H. (1999) The effect of the ecology of toads on the distribution of helminths. Turkish Journal of Zoology 23, 107-110.

Yamaguti, S. (1961) System Helminthum. Volume III: The nematodes of vertebrates. pp. 99-100. New York, Interscience Publishers.

Wilson, M.J., Glen, D.M. \& George, S.K. (1993) The rhabditid nematode Phasmarhabditis hermaphrodita as a potential biological control agent for slugs. Biocontrol Science \& Technology 3, 503-511. 